\title{
Experimental Research on Mercury Catalytic Oxidation over Ce Modified SCR Catalyst
}

\author{
Yadi Qin, Qiyu Weng and Yuqun Zhuo*
}

Key Laboratory for Thermal Science and Power Engineering of the Ministry of Education, Department of Energy and Power Engineering, Tsinghua University, Beijing, 100084, China

*Corresponding Author: Yuqun Zhuo. Email: zhuoyq@mail.tsinghua.edu.cn

Received: 24 December 2020 Accepted: 29 March 2021

\begin{abstract}
In order to improve the ability of SCR catalyst to catalyze the oxidation of gaseous elemental mercury, a series of novel Ce modified SCR (Selection Catalytic Reduction, $\mathrm{V}_{2} \mathrm{O}_{5}-\mathrm{WO}_{3} / \mathrm{TiO}_{2}$ ) catalysts were prepared via two-step ultrasonic impregnation method. The performance of Ce/SCR catalysts on $\mathrm{Hg}^{0}$ oxidation and NO reduction as well as the catalytic mechanism on $\mathrm{Hg}^{0}$ oxidation was also studied. The XRD, BET measurements and XPS were used to characterize the catalysts. The results showed that the pore volume and pore size of catalyst was reduced by Ce doping, and the specific surface area decreased with the increase of Ce content in catalyst. The performance on $\mathrm{Hg}^{0}$ oxidation was promoted by the introduction of $\mathrm{CeO}_{2} \cdot \mathrm{Ce}_{1} / \mathrm{SCR}(1 \% \mathrm{Ce}$, wt.\%) catalyst exhibited the best $\mathrm{Hg}^{0}$ oxidation activity of $21.2 \%$ higher than that of $\mathrm{SCR}$ catalyst at $350^{\circ} \mathrm{C}$, of which the NO conversion efficiency was also higher at $200-400^{\circ} \mathrm{C}$. Furthermore, $\mathrm{Ce}_{1} / \mathrm{SCR}$ showed a better $\mathrm{H}_{2} \mathrm{O}$ resistance but a slightly weaker $\mathrm{SO}_{2}$ resistance than SCR catalyst. The chemisorbed oxygen and weak absorbed oxygen on the surface of catalyst were increased by the addition of $\mathrm{CeO}_{2}$. The chemisorbed oxygen and weak absorbed oxygen on the surface of catalyst were increased by the addition of $\mathrm{CeO}_{2}$. The $\mathrm{Ce}_{1} / \mathrm{SCR}$ possed better redox ability compared with SCR catalyst. $\mathrm{HCl}$ was the most effective gas responsible for the $\mathrm{Hg}^{0}$ oxidation, and the redox cycle $\left(\mathrm{V}^{4+}+\mathrm{Ce}^{4+} \leftrightarrow \mathrm{V}^{5+}+\right.$ $\mathrm{Ce}^{3+}$ ) played an important role in promoting $\mathrm{Hg}^{0}$ oxidation.
\end{abstract}

\section{KEYWORDS}

Mercury catalytic oxidation; SCR catalyst; Ce doping; reaction mechanism

\section{Introduction}

Mercury is considered an important environmental pollutant due to its toxic, bioaccumulative and longdistance transport properties. The global mercury emissions reached 6,500 ton/year in 2014, and it will reach 8,600 tons per year in 2035 according to the ECHMERIT model [1]. In 2013, more than 80 countries and regions, including China, signed the Minamata Convention, which sets the binding standards for mercury-containing products and mercury emissions to atmosphere. Data show that over 3,000 tons of mercury from burning coal are emitted per year globally, and more than $90 \%$ of mercury from coal-fired power plants is released into the atmosphere [2]. After coal combustion, mercury mainly exists in coal cinder, fly ash and flue gas, and the content is about $2 \%, 23.1 \% \sim 26.9 \%$ and $56.3 \% \sim 69.7 \%$, respectively [3]. The average distribution of mercury in flue gas was $56 \%$ elemental mercury $\left(\mathrm{Hg}^{0}\right), 34 \%$ bivalent 
mercury $\left(\mathrm{Hg}^{2+}\right)$ and $10 \%$ particulate mercury $\left(\mathrm{Hg}^{\mathrm{P}}\right)$ [4]. $\mathrm{Hg}^{2+}$ is soluble and easy to react with limestone, more than $80 \%$ of which can be removed by wet limestone-gypsum FGD device [5]. About $90 \%$ of $^{\mathrm{Hg}^{\mathrm{P}}}$ can be captured by electrostatic precipitator, bag filter and other dust removal equipment [6]. However, the air pollution control device (APCDs) has little effect on $\mathrm{Hg}^{0}$ removal [7]. After long-term screening, SCR catalyst with the component of $\mathrm{V}_{2} \mathrm{O}_{5}-\mathrm{WO}_{3}-\mathrm{TiO}_{2}$ is the most widely used in coal-fired power plants. It is found that SCR catalyst can catalyze the conversion of $\mathrm{Hg}^{0}$ to $\mathrm{Hg}^{2+}$, which can be removed by subsequent dedusting and FGD equipment [8]. However, researches showed that $\mathrm{Hg}^{0}$ oxidation over SCR catalyst was limited, highly dependent on the concentration of $\mathrm{HCl}$ in flue gas with poor water resistance [9].

Doping metal oxides into SCR catalysts to improve the oxidation effect of mercury without decreasing the denitrification efficiency has become the focus of current research. $\mathrm{CeO}_{2}$ could provide significant oxygen storage capability through the redox shift between the two oxidation states $\left(\mathrm{Ce}^{3+}\right.$ and $\left.\mathrm{Ce}^{4+}\right)$, which is helpful to enhance catalytic activity [10]. It was found that the catalytic activity of Ce/SCR catalyst was higher than that of $\mathrm{Fe} / \mathrm{SCR}, \mathrm{Mn} / \mathrm{SCR}, \mathrm{Cu} / \mathrm{SCR}$ and $\mathrm{Co} / \mathrm{SCR}$ catalysts [11]. The research of $\mathrm{Ce} / \mathrm{SCR}$ catalyst is still at the initial stage, the optimal temperature for catalytic performance of $\mathrm{Hg}^{0}$ oxidation over $\mathrm{Ce} / \mathrm{SCR}$ catalyst is low due to the large Ce doping amount and the catalyst performs poorly at the normal operating temperature $\left(280^{\circ} \mathrm{C}-420^{\circ} \mathrm{C}\right)$ in power plant [12]. Within the operating temperature range of SCR catalyst in power plant, the optimum amount of Ce doping have not been determined at present [11-14]. Some research such as the effect of flue gas and the mechanism on $\mathrm{Hg}^{0}$ oxidation over Ce modified SCR catalysts also need to be studied.

In this study, a series of $\mathrm{CeO}_{2}$ modified support on $\mathrm{V}_{2} \mathrm{O}_{5}-\mathrm{WO}_{3} / \mathrm{TiO}_{2}$ catalysts were made by ultrasonicassisted impregnation method. The $\mathrm{Hg}^{0}$ and $\mathrm{NO}$ oxidation efficiencies of the catalysts were tested under simulated flue gas. Besides, the effects of individual flue gas components on $\mathrm{Hg}^{0}$ oxidation were also evaluated. Furthermore, X-ray diffraction (XRD), Brunner-Emmet-Teller (BET) and X-ray photoelectron spectroscopy (XPS) were explored to characterize the catalysts, and the reaction mechanism was discussed based on the experimental and characterization results.

\section{Experimental}

\subsection{Catalyst Preparation}

Cerium nitrate which was the precursor of $\mathrm{CeO}_{\mathrm{x}}$ will react with ammonium metavanadate precursor or ammonium tungstate precursor to produce cerium vanadate or cerium tungstate precipitation, affecting the uniformity of $\mathrm{V}_{2} \mathrm{O}_{5}$ and $\mathrm{CeO}_{2}$ on the surface of $\mathrm{TiO}_{2}$. Therefore, modified catalysts were prepared by multi-step ultrasonic impregnation method based on the common commercial SCR catalysts (containing $1 \% \mathrm{~V}_{2} \mathrm{O}_{5}, 9 \% \mathrm{WO}_{3}$ and $90 \% \mathrm{TiO}_{2}$ ). $\mathrm{TiO}_{2}$ was added into mixed solutions of ammonium metavanadate, ammonium metatungstate and oxalic acid. The slurry was exposed to an ultrasonic bath for $4 \mathrm{~h}$, dried at $105^{\circ} \mathrm{C}$ for $4 \mathrm{~h}$ and calcined at $500^{\circ} \mathrm{C}$ for $4 \mathrm{~h}$ in air to obtain $\mathrm{SCR}$ catalyst. $\mathrm{Ce}\left(\mathrm{NO}_{3}\right)_{3}$ was dissolved in deionized water at different concentrations. The powder of SCR catalysts was impregnated in $\mathrm{Ce}\left(\mathrm{NO}_{3}\right)_{3}$ solution for $4 \mathrm{~h}$, dried at $105^{\circ} \mathrm{C}$ for $4 \mathrm{~h}$ and calcined at $500^{\circ} \mathrm{C}$ for $4 \mathrm{~h}$. Finally, $\mathrm{CeO}_{2}$ doped catalyst $\mathrm{V}_{2} \mathrm{O}_{5}-\mathrm{WO}_{3} / \mathrm{TiO}_{2}$ was obtained and abbreviated as $\mathrm{Ce}_{\mathrm{x}} / \mathrm{SCR}$. X represents the mass fraction of Ce in the sample, $\mathrm{x}=0.5 \%, 1 \%, 3 \%, 5 \% .80-100$ mesh particles were selected by stainless steel sieve.

\subsection{Catalytic Activity Test}

The schematic of the fixed-bed reactor system used for $\mathrm{Hg}^{0}$ oxidation was showed in Fig. 1. The reactor system consists of four parts: mercury generation, simulated flue gas mixing, temperature control and mercury analysis. The elemental mercury was generated by a PSA Cavkit 10.534 mercury generator. The water vapor was generated by an IAS Hovocal gas generator. The composition and concentration of simulated flue gas were controlled by mass flow controllers (MFCs). The fixed-bed reactor was made of a quartz tube heated in a vertical tubular furnace. The catalyst sample was placed between the quartz cotton 
and glass fiber filter membrane, which were loaded in the quartz reactor. The concentrations of $\mathrm{Hg}^{0}$ and $\mathrm{Hg}^{2+}$ in simulated flue gas were online monitored by Thermo CEMS. To avoid $\mathrm{Hg}$ contamination, all of the tubes, joints, and valves that $\mathrm{Hg}$ passed through were made of Teflon. To avoid condensation of water vapor, all pipelines with $\mathrm{H}_{2} \mathrm{O}(\mathrm{g})$-containing gas passing through were heated up to $120^{\circ} \mathrm{C}$. The tail gas was treated by an activated carbon trap before being released to the air.

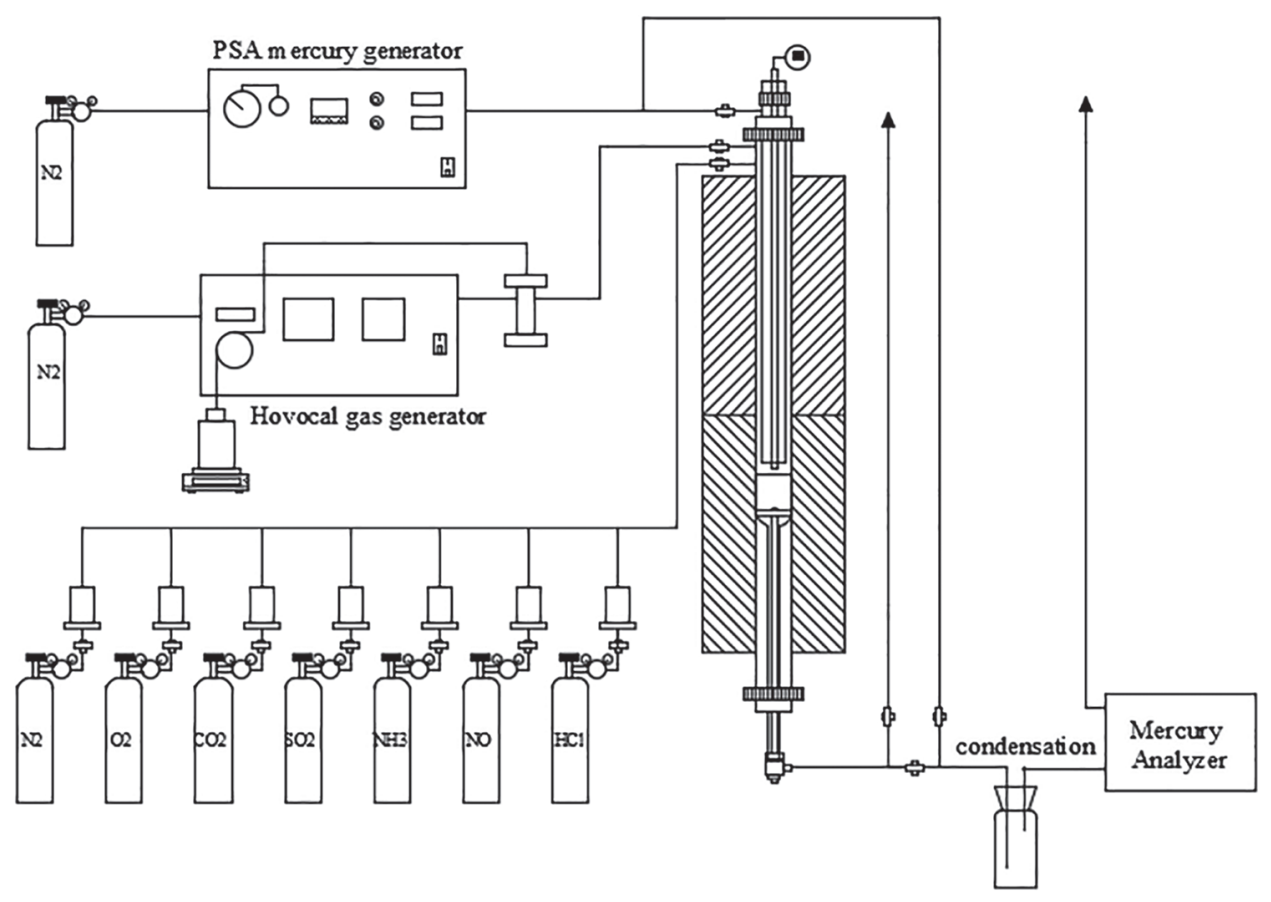

Figure 1: Schematic diagram of experimental system for mercury oxidation

The inlet $\mathrm{Hg}^{0}$ concentration was set at $30 \mu \mathrm{g} / \mathrm{Nm}^{3}$ and the total flow rate of simulated flue gas was controlled at $2 \mathrm{~L} / \mathrm{min}$. The concentration of $\mathrm{Hg}^{0}$ and $\mathrm{Hg}^{2+}$ at the outlet was recorded after adsorption balance, which was defined as the fluctuation of concentration less than $3 \%$. The time for the balance was more than $2 \mathrm{~h}$. The total $\mathrm{Hg}^{0}$ oxidation rate $\left(\mathrm{O}_{\mathrm{xi}}\right)$ within a certain time was defined as follows:

$o_{x i}=\frac{\sum_{t}^{0} \frac{C_{H g^{2+}}^{t}}{C_{H g^{T}}^{t}}}{t}$

where $\mathrm{C}_{\mathrm{Hg}^{2+}}^{t}$ and $\mathrm{C}_{\mathrm{Hg}^{T}}^{t}$ were the outlet $\mathrm{Hg}^{2+}$ and total mercury concentration at the reaction time, respectively.

\subsection{Characterization}

XRD measurements were carried out on polycrystalline X-ray diffractometer (Smartlab, Rigaku, Japan) to examine the crystallinity and dispersivity of crystal pieces using $\mathrm{Cu}$ Ka radiation $(9 \mathrm{KW})$ in the range of $3-90^{\circ}$. The specific surface area, pore volume and pore diameter of catalysts were tested on automatic nitrogen adsorption analyzer (Micrometritics ASAP2010). The surface area and pore size was calculated by Brunauer-Emmett-Teller (BET) method and Barrett-Joyner-Halenda (BJH) method, respectively. To investigate the elemental states, XPS was carried out by X-ray photoelectron spectrometer (PHI QuANTRO SXM, ULVAC-PHI, Japan). The observed spectra were calibrated with the C1s binding energy (BE) value of $284.6 \mathrm{eV}$. 


\section{Results and Discussion}

\section{1 $\mathrm{Hg}^{0}$ Oxidation Activity over Various Catalysts}

Fig. 2 showed the $\mathrm{Hg}^{0}$ catalytic oxidation efficiencies over various catalysts with a space velocity of $60000 \mathrm{~h}^{-1}$ in the temperature range of $150-400^{\circ} \mathrm{C}$. The simulated flue gas consisted of $10 \mathrm{ppm} \mathrm{HCl}, 12 \%$ $\mathrm{CO}_{2}, 5 \% \mathrm{H}_{2}, 300 \mathrm{ppm} \mathrm{NO}, 400 \mathrm{ppm} \mathrm{SO}_{2}$ and $\mathrm{N}_{2}$ as balance gas. The results indicated that Ce doping did not change the optimum $\mathrm{Hg}^{0}$ catalytic oxidation temperature over SCR catalyst, which was still $350^{\circ} \mathrm{C}$. It was clearly found that the addition of $\mathrm{CeO}_{2}$ resulted in enhancement of $\mathrm{Hg}^{0}$ oxidation activity in varying degrees. With the increase of Ce doping, the $\mathrm{Hg}^{0}$ oxidation efficiency over $\mathrm{Ce}_{\mathrm{x}} / \mathrm{SCR}$ catalyst first increased and then decreased at $350^{\circ} \mathrm{C}$. $\mathrm{Ce}_{1} / \mathrm{SCR}$ performed the best mercury oxidation and approximately $84.24 \%$ mercury oxidation efficiency was obtained. It was worth noting that the $\mathrm{Hg}^{0}$ oxidation rate of $\mathrm{Ce}_{5} / \mathrm{SCR}$ decreased remarkably, even less than the $\mathrm{Hg}^{0}$ oxidation rate of SCR when the temperature exceeded $350^{\circ} \mathrm{C}$. It was presumed that $\mathrm{CeO}_{2}-\mathrm{TiO}_{2}$ performed optimal $\mathrm{Hg}^{0}$ catalytic oxidation at about $150^{\circ} \mathrm{C}$ [15], and excessive Ce doping lead to poor $\mathrm{Hg}^{0}$ oxidation over $\mathrm{Ce}_{5} / \mathrm{SCR}$ at high temperature.

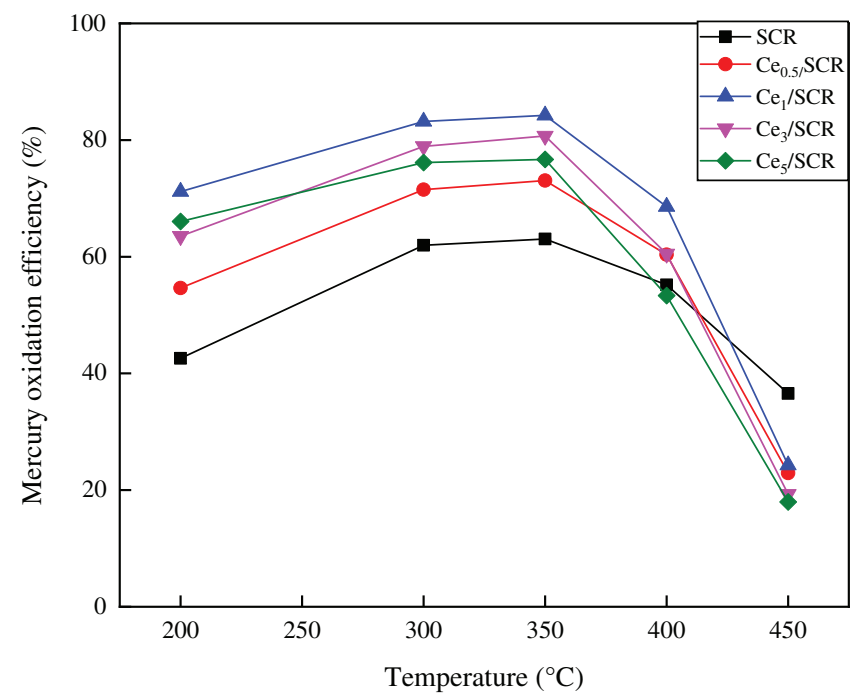

Figure 2: Comparison of catalytic activity for $\mathrm{Hg}^{0}$ oxidation over $\mathrm{Ce}_{\mathrm{x}} / \mathrm{SCR}$ catalysts

\subsection{Effect of Flue Gas Constituents on $\mathrm{Hg}^{\mathrm{O}}$ Oxidation}

\subsubsection{Effect of $\mathrm{SO}_{2}$}

The comparison of effect of $\mathrm{SO}_{2}$ on $\mathrm{Hg}^{0}$ oxidation efficiency over $\mathrm{Ce}_{1} / \mathrm{SCR}$ and $\mathrm{SCR}$ catalyst was measured in Fig. 3. The results indicated that $\mathrm{SO}_{2}$ had a slightly promotional effect on $\mathrm{Hg}^{0}$ oxidation over SCR catalyst. $\mathrm{SO}_{2}$ was oxidized by chemisorbed oxygen to form $\mathrm{SO}_{3}$, which constituted new chemisorption sites for $\mathrm{Hg}^{0}$ and reacted with $\mathrm{Hg}^{0}$ to produce $\mathrm{HgSO}_{4}$ [15]. However, $\mathrm{SO}_{2}$ exhibited a weak inhibiting effect on $\mathrm{Ce}_{1} / \mathrm{SCR}$ catalytic activity. This could be due to that $\mathrm{SO}_{2}$ reacted with $\mathrm{Ce}_{\mathrm{x}} \mathrm{O}_{\mathrm{y}}$ to form $\mathrm{Ce}\left(\mathrm{SO}_{4}\right)_{2}$ and $\mathrm{Ce}_{2}\left(\mathrm{SO}_{4}\right)_{3}$, which reduced the participation of $\mathrm{Ce}_{\mathrm{x}} \mathrm{O}_{\mathrm{y}}$ in $\mathrm{Hg}^{0}$ oxidation process and covered the surface of $\mathrm{Ce}_{1} / \mathrm{SCR}$ catalyst, reducing the contact area between the active components and the reaction gas. Because $\mathrm{Ce}$ content in $\mathrm{Ce}_{1} / \mathrm{SCR}$ catalyst was only $1 \%, \mathrm{SO}_{2}$ had no obvious inhibition on $\mathrm{Hg}^{0}$ oxidation over $\mathrm{Ce}_{1} / \mathrm{SCR}$ catalyst. 


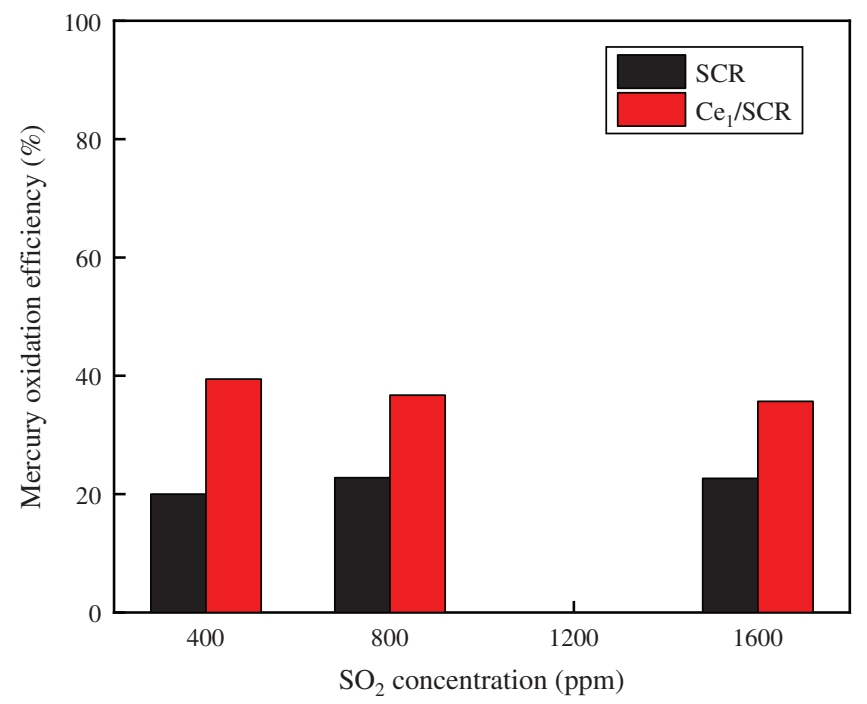

Figure 3: Effect of $\mathrm{SO}_{2}$ on $\mathrm{Hg}^{0}$ oxidation over $\mathrm{SCR}$ and $\mathrm{Ce}_{1} / \mathrm{SCR}$ catalyst at $350^{\circ} \mathrm{C}$. Reaction conditions: $0.6 \mathrm{ppm} \mathrm{HCl}, 5 \% \mathrm{O}_{2}, \mathrm{~N}_{2}$ as balance gas

\subsubsection{Effect of $\mathrm{H}_{2} \mathrm{O}$}

The results that the effect of $\mathrm{H}_{2} \mathrm{O}$ on $\mathrm{Hg}^{0}$ oxidation efficiency over $\mathrm{Ce}_{1} / \mathrm{SCR}$ and SCR catalyst was shown in Fig. 4. $\mathrm{H}_{2} \mathrm{O}$ inhibited $\mathrm{Hg}^{0}$ oxidation due to the competitive adsorption between $\mathrm{H}_{2} \mathrm{O}$ and $\mathrm{Hg}^{0}$ [13]. However, $\mathrm{Ce}_{1} / \mathrm{SCR}$ catalyst had a superior performance of $\mathrm{H}_{2} \mathrm{O}$ resistance than SCR catalyst. It was speculated that the active sites on the surface increased or the adsorption of water vapor decreased by doping Ce into SCR, or the transition between $\mathrm{Ce}^{4+} / \mathrm{Ce}^{3+}$ was likely to offset part of the inhibitory effect of $\mathrm{H}_{2} \mathrm{O}$.

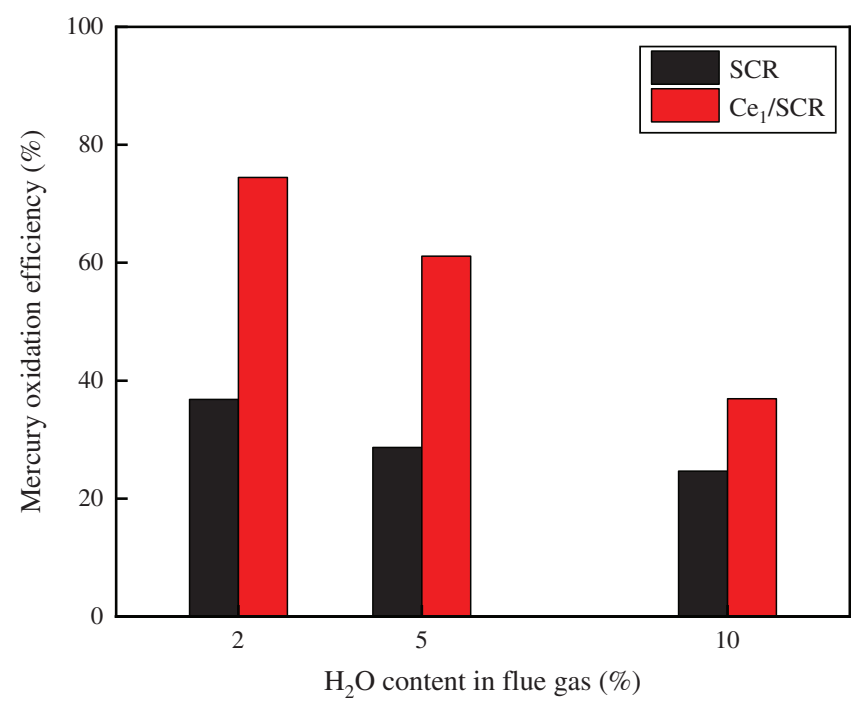

Figure 4: Effect of $\mathrm{H}_{2} \mathrm{O}$ on $\mathrm{Hg}^{0}$ oxidation over $\mathrm{SCR}$ and $\mathrm{Ce}_{1} / \mathrm{SCR}$ catalyst at $350^{\circ} \mathrm{C}$. Reaction conditions: $30 \mathrm{ppm} \mathrm{HCl}, 5 \% \mathrm{O}_{2}, \mathrm{~N}_{2}$ as balance gas, $\mathrm{GHSV}=600000 \mathrm{~h}^{-1}$ 


\subsubsection{Effect of $N O$}

Fig. 5 showed the effect of $\mathrm{NO}$ on $\mathrm{Hg}^{0}$ oxidation over $\mathrm{Ce}_{1} / \mathrm{SCR}$ catalyst. It indicated that $\mathrm{NO}$ had a slight enhancing effect on $\mathrm{Hg}^{0}$ oxidation. This probably because NO reacted with chemisorbed oxygen to form $\mathrm{NO}_{\mathrm{x}}$ species, which could enhance $\mathrm{Hg}^{0}$ oxidation.

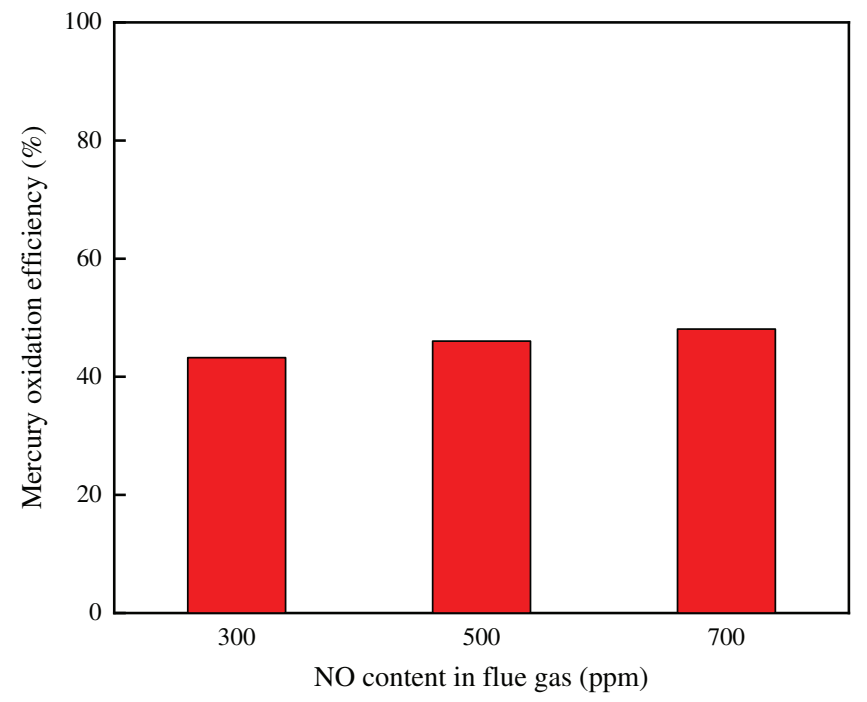

Figure 5: Effect of $\mathrm{NO}$ on $\mathrm{Hg}^{0}$ oxidation over $\mathrm{Ce}_{1} / \mathrm{SCR}$ catalyst at $350^{\circ} \mathrm{C}$. Reaction conditions: $0.6 \mathrm{ppm}$ $\mathrm{HCl}, 5 \% \mathrm{O}_{2}, \mathrm{~N}_{2}$ as balance gas

\subsection{NO Reduction Activity over Various Catalysts}

Catalytic activity evaluation was carried out using a flow-through powder reactor system referred in Pang et al. [16]. NO concentration was tested for $30 \mathrm{~min}$ at each steady state. The NO conversion was calculated using the equation below:

$\mathrm{N}_{\text {oxi }}=\frac{\Delta \overline{\mathrm{NO}}}{\mathrm{NO}_{\text {in }}}=\frac{\mathrm{NO}_{\text {in }}-\overline{\mathrm{NO}_{\text {out }}}}{\mathrm{NO}_{\text {in }}}$

where $\mathrm{NO}_{\text {in }}$ represents the inlet $\mathrm{NO}$ concentration maintained at $500 \mathrm{ppm}$ and $\mathrm{NO}_{\text {out }}$ represents the outlet average $\mathrm{NO}$ concentration.

The NO conversion over SCR and $\mathrm{Ce}_{1} / \mathrm{SCR}$ catalyst at various temperature were showed in Fig. 6 . The NO conversion over SCR catalyst was noticeably enhanced by Ce doping. SCR catalyst performed best NO conversion at $400^{\circ} \mathrm{C}$ while $\mathrm{Ce}_{1} / \mathrm{SCR}$ catalyst performed best at $350^{\circ} \mathrm{C}$. It was speculated that $\mathrm{Ce}$ had a good effect on catalytic oxidation at low temperature, which decreased the optimal denitrification temperature. At operating temperature $\left(300-400^{\circ} \mathrm{C}\right)$ of catalyst in power plant, $\mathrm{NO}$ conversion over $\mathrm{Ce}_{1} / \mathrm{SCR}$ catalyst was greater than 90\%, which had a small difference from the optimal denitrification efficiency. Therefore, $\mathrm{Ce}_{1} / \mathrm{SCR}$ can be well applied in power plant, which will have a better simultaneous removal performance of NO and $\mathrm{Hg}^{0}$ than SCR. 


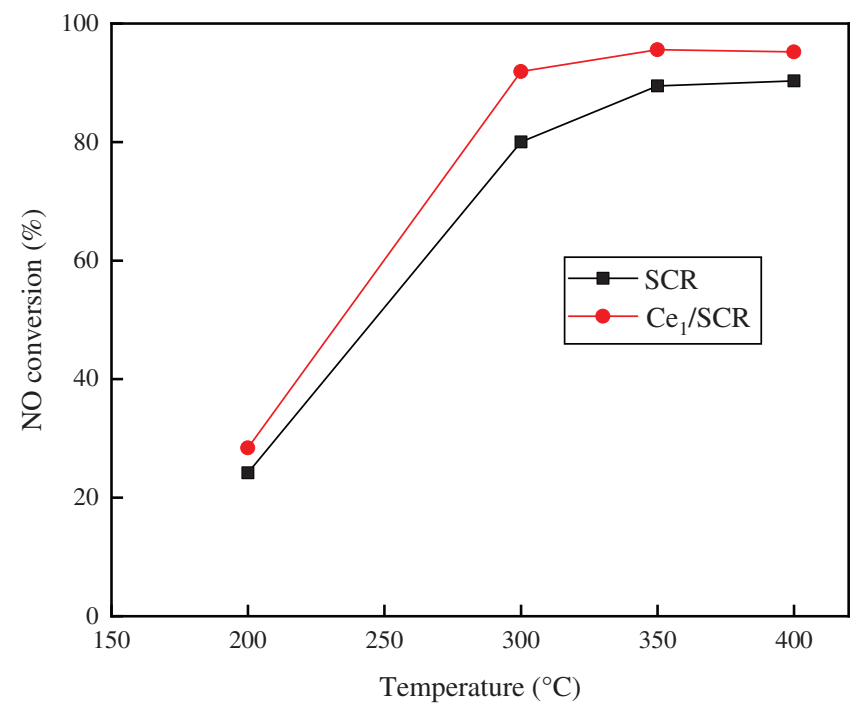

Figure 6: $\mathrm{NO}$ conversion over $\mathrm{SCR}$ and $\mathrm{Ce}_{1} / \mathrm{SCR}$ catalyst. Reaction conditions: $\mathrm{NO} 500 \mathrm{ppm}, \mathrm{NH}_{3}$ $500 \mathrm{ppm}, \mathrm{O}_{2} 3 \%$, and $\mathrm{SO}_{2} 400 \mathrm{ppm}$, balance $\mathrm{N}_{2}$, GHSV $=20000 \mathrm{~h}^{-1}$

\section{Catalyst Characterization}

\subsection{XRD}

The XRD patterns of the raw and modified SCR catalysts were displayed in Fig. 7. $\mathrm{TiO}_{2}$ phase other than rutile $\mathrm{TiO}_{2}$ phase was detected in all samples. The diffraction line of all samples were narrow and sharp, which indicated the high crystallinity. The characteristic peaks of $\mathrm{V}_{2} \mathrm{O}_{5}$ and $\mathrm{WO}_{3}$ were hardly detected, which were due to widely dispersion and poorer crystalline on the surface. $\mathrm{CeO}_{2}$ was not observed when the loading of $\mathrm{Ce}$ was lower than $3 \%$ (wt.\%). There were weak characteristic $\mathrm{CeO}_{2}$ peaks at $28.38^{\circ}$ when the loading of $\mathrm{Ce}$ was $5 \%$, indicating a well-dispersed cluster with a small population of $\mathrm{CeO}_{2}$ may exist.

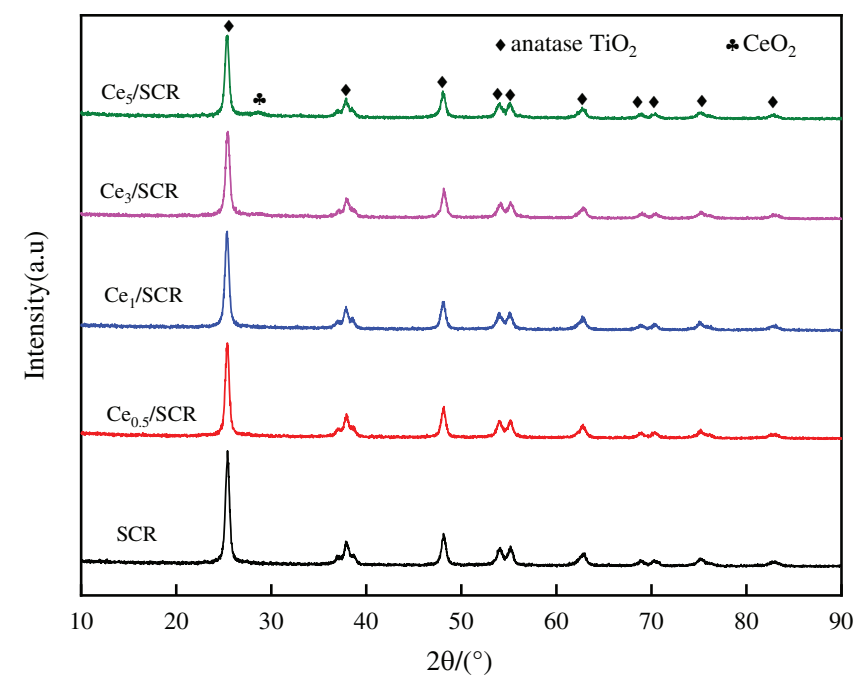

Figure 7: $\mathrm{XRD}$ profiles of $\mathrm{Ce}_{\mathrm{x}} / \mathrm{SCR}$ catalysts with different $\mathrm{Ce}$ contents 


\subsection{BET}

The pore structure parameters of different samples were summarized in Table 1. As can be seen from the result, the BET surface area, $\mathrm{BJH}$ pore volume and average pore volume of $\mathrm{Ce}_{\mathrm{x}} / \mathrm{SCR}$ catalyst were lower than those of SCR. The BET surface area of $\mathrm{Ce}_{\mathrm{x}} / \mathrm{SCR}$ decreased with the increase of Ce doping amount. The pore volume and pore diameter of $\mathrm{Ce}_{\mathrm{x}} / \mathrm{SCR}$ catalyst did not show obvious relationship with Ce doping amount. The Nitrogen adsorption-desorption isotherms of $\mathrm{Ce}_{\mathrm{x}} / \mathrm{SCR}$ were the IV adsorption-desorption isotherm specified by IUPAC. H1 hysteresis loop indicated mesoporous materials, which might facilitate mass transfer in the catalytic reaction (Fig. 8a). As displayed in Fig. 8b, Ce doping had no significant effect on the pore size distribution of catalysts. There were much mesoporous of $2 \sim 50 \mathrm{~nm}$ in $\mathrm{Ce}_{\mathrm{x}} / \mathrm{SCR}$ catalysts, indicating strong interactions between catalyst surface and adsorbate.

Table 1: The specific surface area and crystallite size of the catalysts

\begin{tabular}{llll}
\hline Catalysts & BET surface area $\left(\mathrm{m}^{2} / \mathrm{g}\right)$ & Pore volume $\left(\mathrm{cm}^{3} / \mathrm{g}\right)$ & Average pore diameter $(\mathrm{nm})$ \\
\hline $\mathrm{SCR}$ & 71.9646 & 0.2907 & 161.5863 \\
$\mathrm{Ce}_{0.5} / \mathrm{SCR}$ & 71.8637 & 0.2802 & 155.9777 \\
$\mathrm{Ce}_{1} / \mathrm{SCR}$ & 71.1684 & 0.2543 & 142.9438 \\
$\mathrm{Ce}_{3} / \mathrm{SCR}$ & 70.6369 & 0.2727 & 154.4254 \\
$\mathrm{Ce}_{5} / \mathrm{SCR}$ & 67.8422 & 0.2607 & 153.7143 \\
\hline
\end{tabular}
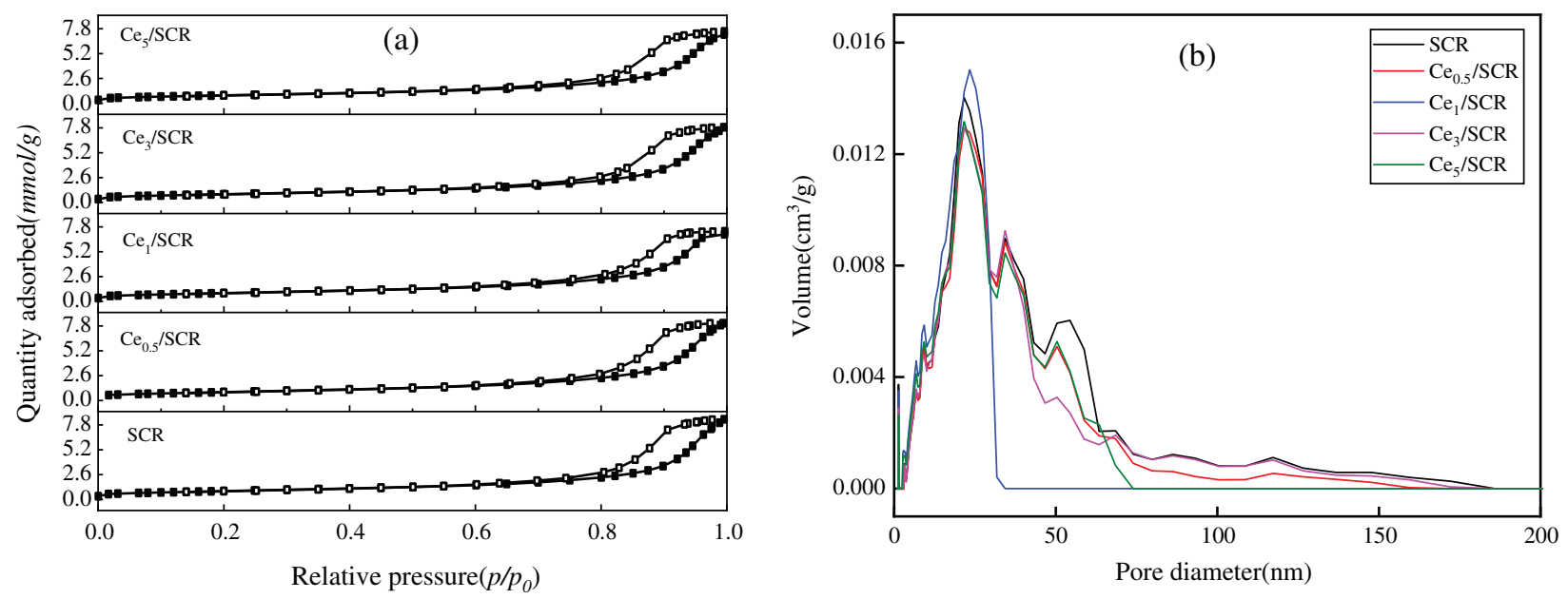

Figure 8: Physical properties of different catalysts. (a) $\mathrm{N}_{2}$ adsorption and desorption isotherms; (b) Particle size distribution

\section{Mechanism}

\section{$5.1 \mathrm{Hg}^{0}$ Oxidation Reaction}

The effects of $\mathrm{HCl}$ and $\mathrm{O}_{2}$ on mercury oxidation over $\mathrm{Ce}_{1} / \mathrm{SCR}$ catalyst were shown in Fig. 9. $\mathrm{Ce}_{1} / \mathrm{SCR}$ catalyst showed less than $5 \%$ mercury oxidation efficiency whether $5 \% \mathrm{O}_{2}$ was introduced into gas stream or not. Considering the measurement error, $\mathrm{O}_{2}$ had little effect on $\mathrm{Hg}^{0}$ oxidation. That was probably because the level of reaction between $\mathrm{O}_{2}$ and $\mathrm{Hg}^{0}$ was low, generating unstable $\mathrm{Hg}^{2+}$ which coule convert to $\mathrm{Hg}^{0}$ easily. 
$2 \mathrm{Hg}+\mathrm{O}_{2} \leftrightharpoons 2 \mathrm{HgO}$

$0.1 \mathrm{ppm} \mathrm{HCl}$ balanced in $\mathrm{N}_{2}$ resulted in $\mathrm{Hg}^{0}$ oxidation efficiency of $13.02 \%$, which is higher than the $2.73 \% \mathrm{Hg}^{0}$ oxidation efficiency under pure $\mathrm{N}_{2}$ condition. $\mathrm{Hg}^{0}$ oxidation efficiency of $64.68 \%$ was observed when $\mathrm{HCl}$ concentration further increased to $1 \mathrm{ppm}$. $\mathrm{HCl}$ exhibited a decisive effect on $\mathrm{Hg}^{0}$ oxidation over $\mathrm{Ce}_{1} / \mathrm{SCR}$ catalyst. $0.1 \mathrm{ppm} \mathrm{HCl}$ resulted in $\mathrm{Hg}^{0}$ oxidation efficiency of $50.42 \%$ with the aid of $5 \% \mathrm{O}_{2}$, indicating more $\mathrm{HCl}$ can be oxidized to form active chlorine species in the presence of $\mathrm{O}_{2}$. That might because $\mathrm{O}_{2}$ replenished the consumed chemisorbed oxygen, regenerated the lattice oxygen and hence maintained the high surface oxygen concentration [15]. The reaction between $\mathrm{HCl}$ and $\mathrm{Ce}_{1} / \mathrm{SCR}$ catalysts may occur through

$2 \mathrm{HCl}+\mathrm{O}=2 \mathrm{Cl}+\mathrm{H}_{2} \mathrm{O}$

$\mathrm{Cl}+\mathrm{Hg}^{0}=\mathrm{HgCl}$

$\mathrm{HgCl}+\mathrm{Cl}=\mathrm{HgCl}_{2}$

where $\mathrm{Cl}$ denoted an active chlorine species for oxidizing $\mathrm{Hg}^{0}$, and $\mathrm{O}$ represented chemisorbed or lattice oxygen on the surface of $\mathrm{Ce}_{1} / \mathrm{SCR}$ catalysts.

The entire reaction can be written as follows:

$\mathrm{Hg}^{0}+2 \mathrm{HCl}+\frac{1}{2} \mathrm{O}=\mathrm{HgCl}_{2}+\mathrm{H}_{2} \mathrm{O}$

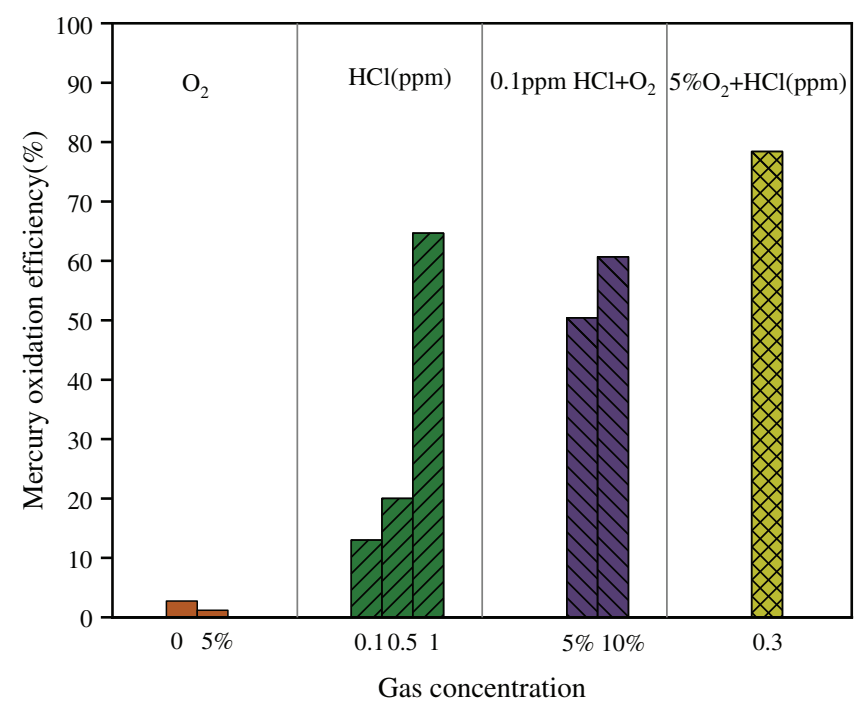

Figure 9: Effects of $\mathrm{HCl}$ and $\mathrm{O}_{2}$ on $\mathrm{Hg}^{0}$ oxidation of $\mathrm{Ce}_{1} / \mathrm{SCR}$ catalyst at $350^{\circ} \mathrm{C}$. Reaction conditions: balance $\mathrm{N}_{2}$, GHSV $=20000 \mathrm{~h}^{-1}$

\section{$5.2 X P S$}

To determine the oxidation states of the element in these catalysts and to further explain the mechanism of $\mathrm{Hg}^{0}$ oxidation over $\mathrm{Ce}_{1} / \mathrm{SCR}$ catalyst, the catalysts were investigated by XPS technique. $\mathrm{Ce}_{1} / \mathrm{SCR}$ catalyst was pretreated in the gas composed of $50 \mu \mathrm{g} / \mathrm{m}^{3}, 10 \mathrm{ppm} \mathrm{HCl}$ and $5 \% \mathrm{O}_{2}$ at $350^{\circ} \mathrm{C}$ for $4 \mathrm{~h}$ to get $\mathrm{sCe}_{1} / \mathrm{SCR}$ catalyst. Fig. 10 showed the O1s XPS spectra for SCR, $\mathrm{Ce}_{1} / \mathrm{SCR}$ and $\mathrm{sCe}_{1} / \mathrm{SCR}$ catalyst. The peak appeared 
at low binding energy (529-530.5 eV) could be ascribed to be the lattice oxygen (denoted as $\mathrm{O}_{\mathrm{b}}$ ) [17], while the binding energy of 531.0-532.9 eV was ascribed to the chemisorbed oxygen and weakly bonded oxygen species (denoted as $\mathrm{O}_{a}$ ) [18]. $\mathrm{O}_{\mathrm{a}}$ has been thought to be the most active oxygen and played an important role in oxidation reaction [18-19]. The surface atomic concentrations of catalysts are given in Table 2. It could be found that $\mathrm{O}_{a}$ relative concentration of $\mathrm{Ce}_{1} / \mathrm{SCR}$ calculated by $\mathrm{O}_{\mathrm{a}} /\left(\mathrm{O}_{\mathrm{a}}+\mathrm{O}_{\mathrm{b}}\right)$ was higher than that of SCR. The reason was that $\mathrm{Ce}$ doping created labile oxygen vacancies, which may conduce to the improvement of chemisorbed oxygen and was helpful for mercury oxidation. The Ce3d spectra of $\mathrm{sCe}_{1} / \mathrm{SCR}$ and $\mathrm{Ce}_{1} / \mathrm{SCR}$ catalysts were presented in Fig. 11. The bands labeled u1 and v1 represent the characteristic peaks of $\mathrm{Ce}^{3+}$ with $3 \mathrm{~d} 104 \mathrm{fl}$ initial electronic state, whereas the peaks labeled $\mathrm{u}, \mathrm{u} 2, \mathrm{u} 3, \mathrm{v}, \mathrm{v} 2$, and v3 represent $\mathrm{Ce}^{4+}$ with $3 \mathrm{~d} 104 \mathrm{f0}$ electronic state [20].

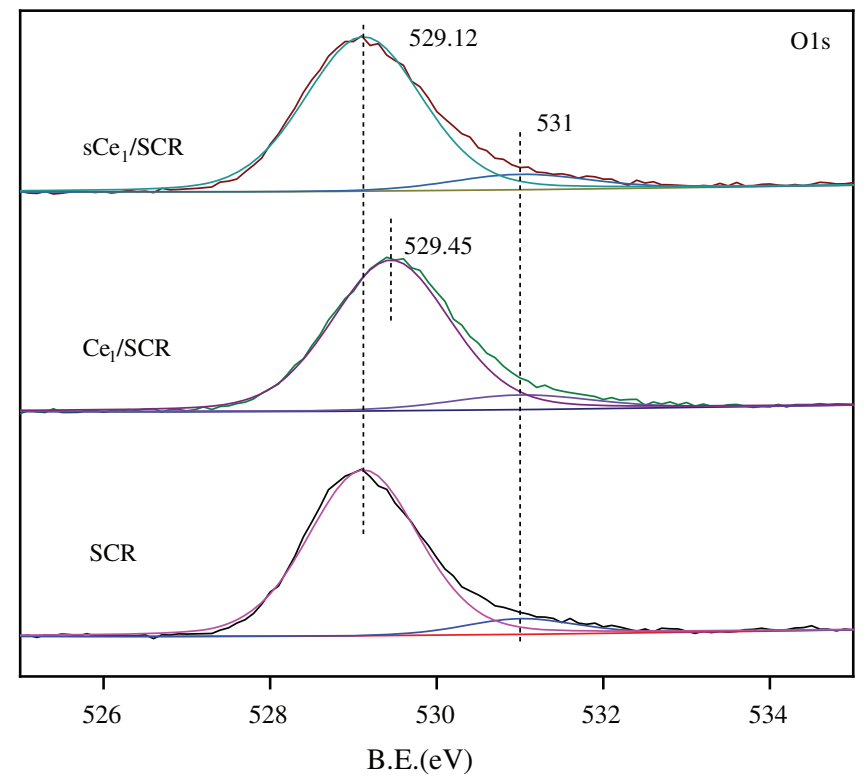

Figure 10: O1s XPS spectra for $\mathrm{SCR}, \mathrm{Ce}_{1} / \mathrm{SCR}$ and $\mathrm{Ce}_{1} / \mathrm{SCR}$

Table 2: Results of quantitative XPS analysis

\begin{tabular}{lll}
\hline Samples & $\mathrm{O}_{\alpha} /\left(\mathrm{O}_{\alpha}+\mathrm{O}_{\beta}\right)$ & $\mathrm{Ce}^{3+} /\left(\mathrm{Ce}^{3+}+\mathrm{Ce}^{4+}\right)$ \\
\hline $\mathrm{SCR}$ & $8.64 \%$ & \\
$\mathrm{Ce}_{1} / \mathrm{SCR}$ & $10.61 \%$ & $33.66 \%$ \\
$\mathrm{SCe}_{1} / \mathrm{SCR}$ & $10.48 \%$ & $29.98 \%$ \\
\hline
\end{tabular}

Table 2 showed a slight change in the Ce valence state ratios after the tests under a flue gas flow. This implied that the redox shift between $\mathrm{Ce}^{3+}$ and $\mathrm{Ce}^{4+}$ happened during the $\mathrm{Hg}^{0}$ catalytic oxidation process. In comparison with $\mathrm{Ce}_{1} / \mathrm{SCR}$, the relative concentration of $\mathrm{Ce}^{3+}$ species decreased in $\mathrm{SCe}_{1} / \mathrm{SCR}$, which might be due to sufficient $\mathrm{O}_{2}$ in flue gas to oxidize $\mathrm{Ce}^{3+}$ to $\mathrm{Ce}^{4+}$.

The $\mathrm{Hg} 4 \mathrm{f}$ XPS profile spectrum of $\mathrm{sCe}_{1} / \mathrm{SCR}$ catalyst was presented in Fig. 12. The binding energies at 101.5 and $110.5 \mathrm{eV}$ was corresponded to $\mathrm{HgCl}_{2}$ and $\mathrm{HgO}$, respectively. $\mathrm{No} \mathrm{Hg}^{0}$ was observed on the surface of $\mathrm{sCe}_{1} / \mathrm{SCR}$ catalyst, which probably because $\mathrm{HCl}$ accelerated $\mathrm{Hg}^{0}$ oxidation. 
EE, 2022, vol.119, no.1

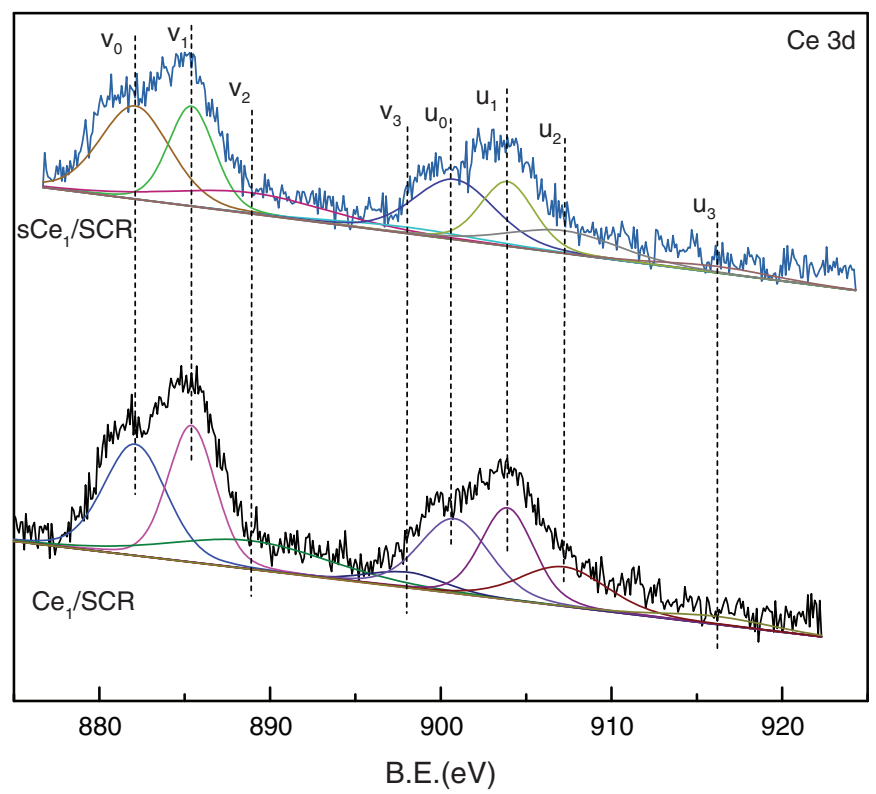

Figure 11: Ce3d XPS spectra for $\mathrm{Ce}_{1} / \mathrm{SCR}$ and $\mathrm{Ce}_{1} / \mathrm{SCR}$

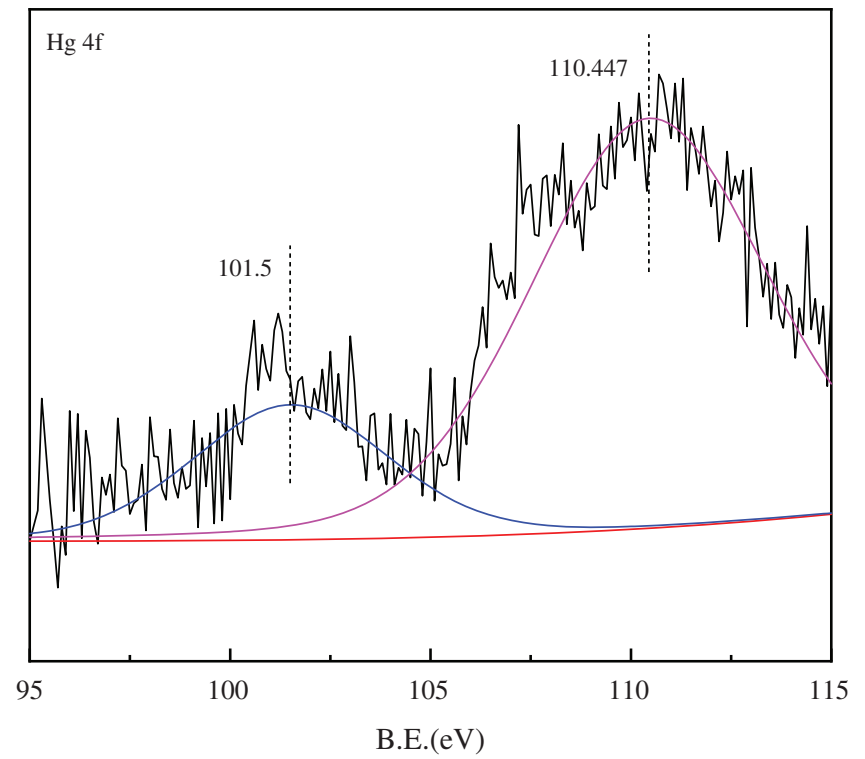

Figure 12: $\mathrm{Hg} 4 \mathrm{f}$ XPS spectra for $\mathrm{sCe}_{1} / \mathrm{SCR}$

\subsection{Mechanism}

Previous studies have shown that the interconversion of $\mathrm{V}^{4+} / \mathrm{V}^{5+}$ participates in the reaction process of $\mathrm{Hg}^{0}$ catalytic oxidation over SCR. Based on the results above, a possible mechanism for $\mathrm{Hg}^{0}$ oxidation can be proposed as follows:

$2 \mathrm{HCl}(\mathrm{g})+\mathrm{V}_{2} \mathrm{O}_{5}=2 \mathrm{Cl}^{*}(\mathrm{ad})+\mathrm{V}_{2} \mathrm{O}_{4}+\mathrm{H}_{2} \mathrm{O}$ 
$2 \mathrm{Cl}(\mathrm{ad})+\operatorname{Hg}^{0}(\mathrm{~g})=\mathrm{HgCl}_{2}(\mathrm{~g})$

$\mathrm{V}_{2} \mathrm{O}_{4}+2 \mathrm{CeO}_{2}=\mathrm{V}_{2} \mathrm{O}_{5}+\mathrm{Ce}_{2} \mathrm{O}_{3}$

$2 \mathrm{Ce}_{2} \mathrm{O}_{3}+\mathrm{O}_{2}=4 \mathrm{CeO}_{2}$

$\mathrm{HCl}$ was adsorbed onto the active sites of catalyst and reacted with chemisorbed oxygen from $\mathrm{V}_{2} \mathrm{O}_{5}$ to form active surface chlorine species, which then would react with gas-phase or weakly bonded $\mathrm{Hg}^{0}$ to produce $\mathrm{HgCl}_{2}$. The redox process of $\mathrm{V}^{4+} / \mathrm{V}^{5+}$ was contributed by the shift of $\mathrm{CeO}_{2} / \mathrm{Ce}_{2} \mathrm{O}_{3}$. The missing lattice oxygen of $\mathrm{CeO}_{2}$ would be replaced by $\mathrm{O}_{2}$. The redox cycle $\left(\mathrm{V}^{4+}+\mathrm{Ce}^{4+} \leftrightarrow \mathrm{V}^{5+}+\mathrm{Ce}^{3+}\right)$ played an important role in promoting $\mathrm{Hg}^{0}$ oxidation.

\section{Conclusion}

Ce doping can significantly improve the catalytic activity for $\mathrm{Hg}^{0}$ oxidation of $\mathrm{SCR}$ catalyst $\mathrm{Ce}_{1} / \mathrm{SCR}$ $\left(1 \% \mathrm{Ce}\right.$, wt.\%) displayed the best performance with an $\mathrm{Hg}^{0}$ oxidation efficiency of $21.2 \%$ higher than that of SCR catalyst in simulated coal-fired flue gas at $350^{\circ} \mathrm{C}$. Ce $\mathrm{e}_{1} / \mathrm{SCR}$ also enhanced $\mathrm{NO}$ conversion efficiency at $200-400^{\circ} \mathrm{C} . \mathrm{H}_{2} \mathrm{O}$ in flue gas had an inhibitive effect on $\mathrm{Hg}^{0}$ oxidation. However, $\mathrm{Ce}_{1} / \mathrm{SCR}$ showed a better $\mathrm{H}_{2} \mathrm{O}$ resistance but a slightly weaker $\mathrm{SO}_{2}$ resistance than SCR catalyst. NO had a slight promotion effect on the $\mathrm{Hg}^{0}$ oxidation over $\mathrm{Ce}_{1} / \mathrm{SCR}$. The XPS results indicated that $\mathrm{Ce}_{1} / \mathrm{SCR}$ possed more chemisorbed oxygen and better redox ability compared with SCR catalyst. The catalytic mechanism was that adsorbed HCl was oxidized by chemisorbed oxygen to form active chlorine which would react with gas-phase or weakly bonded $\mathrm{Hg}^{0}$ to form $\mathrm{HgCl}_{2}$. $\mathrm{HCl}$ played an essential role in $\mathrm{Hg}^{0}$ oxidation, and the redox cycle $\left(\mathrm{V}^{4+}+\mathrm{Ce}^{4+} \leftrightarrow \mathrm{V}^{5+}+\mathrm{Ce}^{3+}\right)$ had an important role in promoting $\mathrm{Hg}^{0}$ oxidation.

Funding Statement: This work was supported by the National Key Research and Development Program of China (No. 2016YFB0600603).

Conflicts of Interest: The authors declare that they have no conflicts of interest to report regarding the present study.

\section{References}

1. Pacyna, J. M., Travnikov, O., de Simone, F., Hedgecock, I. M., Sundseth, K. et al. (2016). Current and future levels of mercury atmospheric pollution on a global scale. Atmospheric Chemistry and Physics, 16(19), 12495-12511. DOI 10.5194/acp-16-12495-2016.

2. Vidic, R. D., McLaughlin, J. B. (1996). Uptake of elemental mercury vapors by activated carbons. Journal of the Air \& Waste Management Association, 46(3), 241-250. DOI 10.1080/10473289.1996.10467458.

3. Ren, J., Zhou, J., Luo, Z., Cen, K. (2002). Study of mercury emission during coal combustion. Acta Scientiae Circumstantiae, 22(3), 289-293. DOI 10.13671/j.hjkxxb.2002.03.004.

4. Zhang, L., Wang, S., Wu, Q., Wang, F., Lin, C. et al. (2016). Mercury transformation and speciation in flue gases from anthropogenic emission sources: A critical review. Atmospheric Chemistry and Physics, 16(4), 2417-2433. DOI 10.5194/acp-16-2417-2016.

5. Wang, Y., Duan, Y., Yang, L., Meng, S., Wang, Q. (2008). Experimental study on mercury removed by combined wet-method flue gas desulphurization devices in combination with electrostatic precipitators. Proceedings of China Electric Machinery Engineering, 28(29), 64-69. DOI 10.13334/j.0258-8013.pcsee.2008.29.003.

6. Yin, L., Zhuo, Y., Xu, Q., Zhu, Z., Du, W. et al. (2013). Mercury emission from coal-fired power plants in China. Proceedings of the CSEE, 33(29), 1-10. DOI 10.13334/j.0258-8013.pcsee.2013.29.004.

7. Xu, W., Wang, J., Wang, W. (2010). Exploratory study of mercury removal effectiveness in various morphology and states during the dust removal and desulphurization treatment of coalfired flue gases. East China Electric Power, 38(1), 47-50. DOI CNKI:SUN:HDDL.0.2010-01-016. 
8. Yan, R., Liang, D. T., Tay, J. H. (2003). Control of mercury vapor emissions from combustion flue gas. Environmental Science and Pollution Research, 10(6), 399-407. DOI 10.1065/espr2003.04.149.

9. Chen, J., Yuan, D., Li, Q., Zheng, J., Zhu, Y. et al. (2008). Effect of flue-gas cleaning devices on mercury emission from coal-fired boiler. Proceedings of the CSEE, 28(2), 72-76. DOI 10.13334/j.0258-8013.pcsee.2008.02.012.

10. Reddy, B. M., Khan, A., Yamada, Y., Kobayashi, T., Loridant, S. et al. (2003). Structural characterization of $\mathrm{CeO}_{2}-$ $\mathrm{TiO}_{2}$ and $\mathrm{V}_{2} \mathrm{O}_{5} / \mathrm{CeO}_{2}-\mathrm{TiO}_{2}$ catalysts by Raman and XPS techniques. Journal of Physical Chemistry B, 107(22), 5162-5167. DOI 10.1021/jp0344601.

11. Chi, G., Shen, B., Zhu, S., Chuan, H. (2016). Oxidation of elemental mercury over modified SCR catalysts. Journal of Fuel Chemistry and Technology, 44(6), 763-768. DOI 10.3969/j.issn.0253-2409.2016.06.018.

12. Zhao, L., Li, C., Zhang, J., Zhang, X., Zhan, F. et al. (2015). Promotional effect of $\mathrm{CeO}_{2}$ modified support on $\mathrm{V}_{2} \mathrm{O}_{5}-\mathrm{WO}_{3} / \mathrm{TiO}_{2}$ catalyst for elemental mercury oxidation in simulated coal-fired flue gas. Fuel, 153, 361-369. DOI 10.1016/j.fuel.2015.03.001.

13. Chi, G., Shen, B., Yu, R., He, C., Zhang, X. (2017). Simultaneous removal of NO and $\mathrm{Hg}^{0}$ over Ce-cu modified $\mathrm{V}_{2} \mathrm{O}_{5} / \mathrm{TiO}_{2}$ based commercial SCR catalysts. Journal of Hazardous Materials, 330, 83-92. DOI 10.1016/j. jhazmat.2017.02.013.

14. Zhao, L., He, Q. S., Li, L., Lu, Q., Dong, C. Q. et al. (2015). Research on the catalytic oxidation of $\mathrm{Hg}^{0}$ by modified SCR catalysts. Journal of Fuel Chemistry and Technology, 43(5), 628-634. DOI 10.1016/S1872-5813(15)30018-9.

15. Li, H., Wu, C., Li, Y., Zhang, J. (2011). $\mathrm{CeO}_{2}-\mathrm{TiO}_{2}$ catalysts for catalytic oxidation of elemental mercury in lowrank coal combustion flue Gas. Environmental Science \& Technology, 45(17), 7394-7400. DOI 10.1021/ es2007808.

16. Pang, C., Zhuo, Y., Weng, Q. (2017). Mn/SAPO-34 as an efficient catalyst for the low-temperature selective catalytic reduction of $\mathrm{NO}_{\mathrm{x}}$ with $\mathrm{NH}_{3}$. RSC Advances, 7(51), 32146-32154. DOI 10.1039/C7RA05165D.

17. Shan, W., Liu, F., He, H., Shi, X., Zhang, C. (2012). A superior Ce-W-Ti mixed oxide catalyst for the selective catalytic reduction of $\mathrm{NOx}$ with $\mathrm{NH}_{3}$. Applied Catalystis B: Environmental, 115, 100-106. DOI 10.1016/j. apcatb.2011.12.019.

18. Fang, J., Bi, X., Si, D., Jiang, Z., Huang, W. (2007). Spectroscopic studies of interfacial structures of $\mathrm{CeO}_{2}-\mathrm{TiO}_{2}$ mixed oxides. Applied Surface Science, 253(22), 8952-8961. DOI 10.1016/j.apsusc.2007.05.013.

19. Wang, P., Su, S., Xiang, J., Cao, F., Sun, L. et al. (2013). Atalytic oxidation of $\mathrm{Hg}^{0}$ by $\mathrm{CuO}-\mathrm{MnO}_{2}-\mathrm{Fe}_{2} \mathrm{O}_{3}-\mathrm{Al}_{2} \mathrm{O}_{3}$ catalyst. Chemical Engineering Journal, 225, 68-75. DOI 10.1016/j.cej.2013.03.060.

20. He, H., Dai, H. X., Au, C. T. (2004). Defective structure, oxygen mobility, oxygen storage capacity, and redox properties of RE-based $(\mathrm{RE}=\mathrm{Ce}, \mathrm{Pr}$ ) solid solutions. Catalysis Today, 90(3-4), 245-254. DOI 10.1016/j. cattod.2004.04.033. 